\title{
АНАЛИЗ КАДАСТРОВОЙ ОЦЕНКИ ЗЕМЕЛЬНЫХ УЧАСТКОВ В СОСТАВЕ ЗЕМЕЛЬ СЕЛЬСКОХОЗЯЙСТВЕННОГО НАЗНАЧЕНИЯ НА ТЕРРИТОРИИ НОВОСИБИРСКОЙ ОБЛАСТИ
}

\section{Александр Владимирович Комиссаров}

Сибирский государственный университет геосистем и технологий, 630108, Россия, г. Новосибирск, ул. Плахотного, 10, доктор технических наук, зав. кафедрой фотограмметрии и дистанционного зондирования, тел. (383)361-08-66, e-mail: avkom82@mail.ru

\section{Милена Юрьевна Репотецкая}

Министерство природных ресурсов и экологии Новосибирской области, 630099, Россия, г. Новосибирск, Красный проспект, 25, главный эксперт, тел. (383)296-51-95, e-mail: ru-milena@mail.ru

\section{Денис Вадимович Арутюнов}

Сибирский государственный университет геосистем и технологий, 630108, Россия, г. Новосибирск, ул. Плахотного, 10, обучающийся, тел. (953)768-74-10, e-mail: qwerty02059682@gmail.com

В статье проведен анализ результатов государственной кадастровой оценки земель сельскохозяйственного назначения на территории Новосибирской области за 2020 год. Рассмотрена динамика кадастровой стоимости земельных участков в составе земель сельскохозяйственного назначения в разрезе муниципальных районов за 2015 и 2020 годы и выявлены основные недостатки результатов оценки земельных участков.

Ключевые слова: государственная кадастровая оценка земель, земли сельскохозяйственного назначения, сельскохозяйственные угодья, земельный участок, кадастровая стоимость

\section{ANALYSIS OF THE CADASTRIAL VALUE OF AGRICULTURAL LAND IN NOVOSIBIRSK REGION}

\section{Alexandr V. Komissarov}

Siberian State University of Geosystems and Technologies, 10, Plakhotnogo St., Novosibirsk, 630108, Russia, D. Sc., Head of the Department of Photogrammetry and Remote Sensing, phone: (383)361-08-66, e-mail: avkom82@mail.ru

\section{Milena Yu. Repotetskaya}

Ministry of Natural Resources and Ecology of the Novosibirsk Region, 25, Krasny Ave., Novosibirsk, 630099, Russia, Chief Expert, phone: (383)296-51-95, e-mail: ru-milena@mail.ru

\section{Denis V. Arutyunov}

Siberian State University of Geosystems and Technologies, 10, Plakhotnogo St., Novosibirsk, 630108, Russia, Student, phone: (953)768-74-10, e-mail: qwerty02059682@gmail.com

The article analyzes the results of the state cadastral valuation of agricultural land in the territory of the Novosibirsk Region for 2020. The dynamic of the cadastral value of agricultural land by municipal districts for 2015 and 2020 is considered and the results of the assessment of land plots are revealed.

Keywords: state cadastral valuation of land, agricultural land, farmland, land plot, cadastral value 


\section{Введение}

В настоящее время невозможно представить человеческую деятельность без использования земли. Земля является природным ресурсом, благом, которое обладает высокой ценностью и стоимостью.

Как объект недвижимости она представляет собой территорию с определенными границами и может использоваться с целью получения дохода или возможностью проживания [1].

Земельные участки все чаще становятся объектами товарно-хозяйственных отношений. Одним из этих отношений является оценка стоимости земли.

Анализ стоимости земель сельскохозяйственного назначения на территории Новосибирской области является актуальной темой. Обусловлено это тем, что земля введена в гражданский оборот, иными словами общество может приобретать земельные участки под частную собственность, а также в 2020 году проведена государственная кадастровая оценка земельных участков данной категории земель.

Результаты объективной оценки земельных участков необходимы государственным и муниципальным органам власти, а также юридическим и физическим лицам при совершении разного рода сделок с землей.

Цель исследования - проведение анализа кадастровой оценки земельных участков в составе земель сельскохозяйственного назначения на территории Новосибирской области.

Объектом исследования выступают земельные участки в составе земель сельскохозяйственного назначения на территории Новосибирской области.

\section{Эксперименты}

Информационной базой исследования послужил департамент имущества и земельных отношений Новосибирской области.

По данным государственного кадастрового учета на 01.01.2020 года земельный фонд Новосибирской области составляет 17 775,6 тыс. га [2].

Согласно ст. 7 Земельного кодекса Российской Федерации, по целевому назначению земли подразделяются на семь основных категорий [3]:

- земли сельскохозяйственного назначения;

- земли населенных пунктов;

- земли промышленности, энергетики, транспорта, связи, радиовещания, телевидения, информатики, земли для обеспечения космической деятельности, земли обороны, безопасности и земли иного специального назначения;

- земли особо охраняемых территорий и объектов;

- земли лесного фонда;

- земли водного фонда;

- земли запаса. 
В фонде земли Новосибирской области основную часть территории занимают земли сельскохозяйственного назначения, общая площадь которых составляет 11128,5 тыс. га или $62,6 \%$ от общей площади региона [2].

В состав земель сельскохозяйственного назначения включены сельскохозяйственные угодья (пашня, сенокосы, пастбища, залежь, многолетние насаждения), их площадь составляет 7654,2 тыс. га (68,7 \% от общей площади земель сельскохозяйственного назначения) и несельскохозяйственные земли, занятые внутрихозяйственными дорогами, коммуникациями, мелиоративными защитными лесными насаждениями, водными объектами, зданиями и сооружениями, используемыми для производства, хранения и первичной переработки сельхозпродукции, площадью 3474,3 тыс. га (31,3 \% от общей площади земель данной категории) [2].

Результаты определения кадастровой стоимости земельных участков в составе земель сельскохозяйственного назначения были утверждены приказом департамента имущества и земельных отношений Новосибирской области от 26.11.2015 № 2545 [4].

В связи с необходимостью актуализации результатов определения кадастровой стоимости земельных участков в составе земель сельскохозяйственного назначения, в 2020 году проведена государственная кадастровая оценка данных земельных участков на территории Новосибирской области (далее - ГКОЗ СХ) [5-9].

При проведении ГКОЗ СХ в 2015 году выделено 6 основных групп сельскохозяйственного назначения [4]:

- 1 группа - земли, пригодные под пашни, сенокосы и пастбища, а также предназначенные для защиты земель от воздействия природных явлений;

- 2 группа - земли, малопригодные под пашню, но используемые для выращивания некоторых видов агрокультур;

- 3 группа - земли, занятые зданиями, строениями, сооружениями используемые для производства, хранения и первичной переработки сельскохозяйственных культур;

- 4 группа - земли, занятые водными объектами и используемые для предпринимательской деятельности;

- 5 группа - земли, на которых располагаются леса;

- 6 группа - прочие земли, в том числе болота, овраги, полигоны, свалки.

В настоящее время для целей определения кадастровой стоимости земельные участки группируются в соответствии с кодами расчета видов использования на 14 основных сегментов [6]:

- «Сельскохозяйственное использование»;

- «Жилая застройка (среднеэтажная и многоэтажная)»;

- «Общественное использование»;

- «Предпринимательство»;

- «Отдых (рекреация)»; 
- «Производственная деятельность»;

- «Транспорт»;

- «Обеспечение обороны и безопасности»;

- «Охраняемые природные территории и благоустройство»;

- «Использование лесов»;

- «Водные объекты»;

- «Специальное, ритуальное использование, запас»;

- «Садоводческое, огородническое и дачное использование, малоэтажная жилая застройка»;

- «Иное использование» - вид использования земельных участков, не указанный в предыдущих 13 сегментах.

Общее количество земельных участков из состава земель сельскохозяйственного назначения, подлежащих ГКОЗ СХ, составляет 267535.

В данном исследовании наибольший интерес представляет первая группа «Сельскохозяйственное использование» $[10,11]$. При расчете кадастровой стоимости объектов оценки, входящих в первую группу, для каждого объекта оценки введены корректировки на отличия типового объекта от объектов оценки по следующим основным ценообразующим факторам:

- площадь;

- форма участка (конфигурация);

- расположение относительно автомагистралей, площадь;

- удаление объекта от административного центра субъекта;

- удаление объекта от административного центра муниципального района.

В проведенной государственной кадастровой оценке земельных участков данной категории земель не применялись следующие ценообразующие факторы: вид угодий, коэффициент протяженности земельного участка по данным геоинформационных систем (ГИС), наличие обременений (ограничений) земельного участка, нормативная урожайность, гранулометрический состав почв (механический состав), каменистость почв, засоление, солонцеватость, карбонатность, уплотнение почв, переувлажнение, наличие неудобиц (степень изрезанности рельефом), пестрота почвенного покрова, удаленность от рынков сбыта, расположение земельного участка относительно линий электропередач, магистральных газопроводов и др.

Итоговые значения удельного показателя кадастровой стоимости (далее - УПКС) типового (эталонного) объекта оценки для каждой оценочной зоны первой группы в сравнении со средними значениями УПКС первой группы по результатам оценки 2015 года $[4,6]$ представлены в табл. 1.

Из табл. 1 видно, что в Болотнинском, Доволенском, Карасукском, Кочковском, Краснозерском, Купинском и Татарском районах УПКС первой группы земельных участков уменьшился в 2020 году по сравнению с 2015 годом. В таких 
районах, как Новосибирский, Ордынский, Коченевский, Кыштовский, Северный, Искитимский, Чулымский, Колыванский произошло существенное увеличение УПКС первой группы земельных участков (более 100 \% по сравнению с оценкой 2015 года).

Таблий 1

Результаты расчета УПКС типового (эталонного) объекта первой группы

\begin{tabular}{|c|c|c|c|c|}
\hline \multicolumn{3}{|c|}{2020 год } & \multirow{2}{*}{$\begin{array}{c}2015 \text { год } \\
\text { УПКС, } \\
\text { руб./кв.м }\end{array}$} & \multirow[t]{2}{*}{$\begin{array}{c}\text { Изменение, } \\
\%\end{array}$} \\
\hline Зона & $\begin{array}{l}\text { Районы Новоси- } \\
\text { бирской области }\end{array}$ & $\begin{array}{l}\text { УПКСоэ, } \\
\text { руб./кв.м. }\end{array}$ & & \\
\hline Новосибирская & Новосибирский & 10,78 & 2,44 & 342 \\
\hline Ордынская & Ордынский & 8,35 & 2,57 & 225 \\
\hline Искитимская & Искитимский & 6,03 & 2,60 & 132 \\
\hline Коченевская & Коченевский & 8,51 & 2,00 & 326 \\
\hline $\begin{array}{l}\text { Мошковско-Тогучин- } \\
\text { ская }\end{array}$ & $\begin{array}{l}\text { Мошковский } \\
\text { Тогучинский }\end{array}$ & 4,06 & $\begin{array}{l}2,35 \\
2,51\end{array}$ & $\begin{array}{l}73 \\
62 \\
\end{array}$ \\
\hline $\begin{array}{l}\text { Колыванско-Чулым- } \\
\text { ская }\end{array}$ & $\begin{array}{l}\text { Колыванский } \\
\text { Чулымский }\end{array}$ & 3,07 & $\begin{array}{l}1,41 \\
1,09\end{array}$ & $\begin{array}{l}118 \\
182 \\
\end{array}$ \\
\hline $\begin{array}{c}\text { Черепан-Маслян- } \\
\text { Сузунская }\end{array}$ & $\begin{array}{l}\text { Черепановский } \\
\text { Маслянинский } \\
\text { Сузунский }\end{array}$ & 2,67 & $\begin{array}{l}2,57 \\
2,09 \\
2,49\end{array}$ & $\begin{array}{c}4 \\
28 \\
7 \\
\end{array}$ \\
\hline Болотнинская & Болотнинский & 2,16 & 2,41 & -10 \\
\hline Прочая & $\begin{array}{l}\text { Баганский Бара- } \\
\text { бинский } \\
\text { Венгеровский } \\
\text { Доволенский } \\
\text { Здвинский } \\
\text { Карасукский } \\
\text { Каргатский } \\
\text { Кочковский } \\
\text { Краснозерский } \\
\text { Куйбышевский } \\
\text { Купинский Кы- } \\
\text { штовский } \\
\text { Северный } \\
\text { Татарский } \\
\text { Убинский } \\
\text { Усть-Тарский } \\
\text { Чановский Чисто- } \\
\text { озерный }\end{array}$ & 1,31 & \begin{tabular}{l|l}
1,29 \\
1,02 \\
1,03 \\
1,37 \\
1,18 \\
1,38 \\
1,13 \\
2,10 \\
1,93 \\
1,12 \\
1,48 \\
0,31 \\
0,31 \\
1,39 \\
0,90 \\
0,99 \\
1,05 \\
0,94
\end{tabular} & $\begin{array}{c}2 \\
28 \\
27 \\
-4 \\
11 \\
-5 \\
16 \\
-38 \\
-32 \\
17 \\
-11 \\
323 \\
323 \\
-6 \\
46 \\
32 \\
25 \\
39 \\
\end{array}$ \\
\hline
\end{tabular}

В табл. 2 приведены значения минимальных, средних и максимальных значений УПКС земельных участков из состава земель сельскохозяйственного назначения в разрезе муниципальных районов Новосибирской области по результатам ГКОЗ СХ 2020 года [6]. 
Таблиия 2

Значения УПКС земельных участков из состава земель сельскохозяйственного назначения на территории Новосибирской области

\begin{tabular}{|c|c|c|c|c|c|}
\hline $\begin{array}{c}\text { № } \\
\text { II/ } \\
\text { II }\end{array}$ & $\begin{array}{l}\text { Наименование муни- } \\
\text { ципального района }\end{array}$ & $\begin{array}{l}\text { Количество, } \\
\text { ед. }\end{array}$ & $\begin{array}{c}\text { Минималь- } \\
\text { ное значение } \\
\text { УПКС, } \\
\text { руб./кв.м. }\end{array}$ & $\begin{array}{c}\text { Среднее } \\
\text { значение } \\
\text { УПКС, } \\
\text { руб./кв.м } \\
\text {. }\end{array}$ & $\begin{array}{c}\text { Максималь- } \\
\text { ное значение } \\
\text { УПКС, } \\
\text { руб./кв.м. }\end{array}$ \\
\hline 1 & Баганский & 622 & 0,65 & 0,88 & 11,13 \\
\hline 2 & Барабинский & 1314 & 0,48 & 0,97 & 268,11 \\
\hline 3 & Болотнинский & 2524 & 1,07 & 1,69 & 498,27 \\
\hline 4 & Венгеровский & 584 & 0,47 & 0,89 & 216,04 \\
\hline 5 & Доволенский & 993 & 0,65 & 0,98 & 232,13 \\
\hline 6 & Здвинский & 888 & 0,50 & 0,91 & 360,80 \\
\hline 7 & Искитимский & 17271 & 0,52 & 4,87 & 2219,53 \\
\hline 8 & Карасукский & 5131 & 0,65 & 0,94 & 396,68 \\
\hline 9 & Каргатский & 640 & 0,65 & 2,04 & 950,36 \\
\hline 10 & Колыванский & 17097 & 0,05 & 2,61 & 432,25 \\
\hline 11 & Коченевский & 25882 & 0,77 & 5,50 & 554,49 \\
\hline 12 & Кочковский & 826 & 0,65 & 0,97 & 638,68 \\
\hline 13 & Краснозерский & 3918 & 0,65 & 0,97 & 476,74 \\
\hline 14 & Куйбышевский & 698 & 0,65 & 0,92 & 466,68 \\
\hline 15 & Купинский & 1299 & 0,65 & 0,89 & 250,88 \\
\hline 16 & Кыштовский & 147 & 0,32 & 0,89 & 172,47 \\
\hline 17 & Маслянинский & 1455 & 1,33 & 1,90 & 430,75 \\
\hline 18 & Мошковский & 27079 & 1,20 & 4,35 & 546,86 \\
\hline 19 & Новосибирский & 122284 & 0,38 & 28,40 & 1798,70 \\
\hline 20 & Ордынский & 8249 & 0,62 & 6,86 & 1000,03 \\
\hline 21 & Северный & 203 & 0,13 & 0,91 & 232,13 \\
\hline 22 & Сузунский & 994 & 1,33 & 2,12 & 381,20 \\
\hline 23 & Татарский & 3436 & 0,65 & 0,95 & 435,99 \\
\hline 24 & Тогучинский & 12052 & 1,71 & 2,81 & 575,68 \\
\hline 25 & Убинский & 526 & 0,27 & 1,20 & 488,09 \\
\hline 26 & Усть-Таркский & 451 & 0,65 & 0,85 & 181,55 \\
\hline 27 & Чановский & 2091 & 0,65 & 0,97 & 264,08 \\
\hline 28 & Черепановский & 2217 & 1,33 & 2,13 & 477,11 \\
\hline 29 & Чистоозерный & 2030 & 0,65 & 0,93 & 264,08 \\
\hline \multirow[t]{2}{*}{30} & Чулымский & 792 & 0,67 & 2,06 & 547,39 \\
\hline & По области & 267535 & 0,05 & 2,20 & 2219,53 \\
\hline
\end{tabular}

Среднее значение УПКС земельных участков рассчитано, как отношение суммарного значения кадастровой стоимости земельных участков к суммарному значению общей площади объектов недвижимости в разрезе муниципальных образований Новосибирской области [6]. 
Анализ соотношений минимальных, средних и максимальных значений УПКС показал большой диапазон значений УПКС, так, например, в Искитимском районе минимальное значение - 0,52 руб./кв.м, максимальное - 2219,53 руб./кв.м, Новосибирском районе минимальное значение - 0,38 руб./кв.м, максимальное 1798,70 руб./кв.м, Ордынском районе минимальное значение - 0,62 руб./кв.м, максимальное - 1000,03 руб./кв.м.

\section{Заключение}

Проанализировав результаты проведенной в 2020 году ГКОЗ СХ выявлено, что для целей определения кадастровой стоимости земельные участки группируются в соответствии с кодами расчета видов использования на 14 основных сегментов в отличие от ГКОЗ СХ 2015 года, где было выделено 6 основных групп сельскохозяйственного назначения.

Для расчета первой группы «Сельскохозяйственное использование» выделено 9 оценочных зон (Новосибирская, Ордынская, Искитимская, Коченевская, Мошковско-Тогучинская, Колыванско-Чулымская, Черепан-Маслян-Сузунская, Болотнинская, Прочая), в 2015 году указаны четыре природно-сельскохозяйственные зоны (Привасюганская, Барабинская, Северо-Кулундинская и Центрально-Восточная).

При расчете кадастровой стоимости земельных участков данной категории земель применены не все ценообразующие факторы, влияющие на стоимость, например, вид угодий, нормативная урожайность, гранулометрический состав почв (механический состав), каменистость почв, засоление, переувлажнение, расположение земельного участка относительно линий электропередач, магистральных газопроводов и др.

Выявлено, что в 7 муниципальных районах УПКС первой группы земельных участков уменьшился в 2020 году по сравнению с 2015 годом, а в 8 муниципальных районах произошло существенное увеличение УПКС первой группы земельных участков (более 100 процентов от средних УПКС 2015 года).

Анализ соотношений минимальных, средних и максимальных значений УПКС показал большой диапазон значений УПКС.

\section{БИБЛИОГРАФИЧЕСКИЙ СПИСОК}

1. Кресникова Н.И. Земельный рынок России: институциональные аспекты // Аграрная Россия. 2016. № 1. С. 26-28.

2. Доклад о состоянии и использовании земель Новосибирской области в 2019 году [Электронный ресурс]. - Режим доступа: http://www.to54.rosreestr.ru/.

3. Земельный кодекс Российской Федерации [Электронный ресурс] : Федеральный закон от 25.10.2001 №136-Ф3. - Режим доступа: http://www.consultant.ru/ (C) КонсультантПлюс.

4. Приказ департамента имущества и земельных отношений Новосибирской области № 2545 от 26.11.2015 [Электронный ресурс]. - Режим доступа: http://dizo.nso.ru/page/53/. 
5. Приказ Департамента имущества и земельных отношений Новосибирской области от 15.08.2019 г. № 3442 URL: http://dizo.nso.ru/page/53/.

6. Отчет № 5-CX/2020 «Об итогах государственной кадастровой оценки земельных участков в составе земель сельскохозяйственного назначения на территории Новосибирской области [Электронный ресурс]. - Режим доступа: http://noti.ru/ocenka1/.

7. Об утверждении методических рекомендаций по государственной кадастровой оценке земель сельскохозяйственного назначения [Электронный ресурс]: Приказ Минэкономразвития России от 04.07.2005 № 145 (ред. от 08.07.2011). - Режим доступа: http://www.consultant.ru/document/cons_doc_LAW_55333/.

8. Об утверждении классификатора видов разрешенного использования земельных участков [Электронный ресурс]: Приказ Минэкономразвития России от 01.09.2014 № 540 (ред. от 04.02.2019). - Режим доступа: http://www.consultant.ru/document/cons_doc_LAW_168733/.

9. Об утверждении методических указаний о государственной кадастровой оценке [Электронный ресурс]: Приказ Минэкономразвития России от 12.05.2017 г. № 226 (ред. от 09.09.2019). - Режим доступа: http://www.consultant.ru/document/cons_doc_LAW_217405/.

10. Сучков А.И, Репотецкая М.Ю, Рыхта П.А. Анализ современного состояния и использования земель сельскохозяйственного назначения в Новосибирской области // Вестник Новосибирского государственного аграрного университета, № 3 (32), 2014. - С. 125-130.

11. Комиссаров А.В, Репотецкая М.Ю. Проблемы государственной кадастровой оценки земель сельскохозяйственного назначения на территории Новосибирской области // ИТЕРЭКСПО ГЕО-СИБИРЬ-2018», Сб.: МатериалЫ ХIV международного научн. конгресса «Т. 3, ч. 2., 23-27 апреля 2018 г. - Новосибирск: СГУГИТ, 2018. - С. 301-311.

(C) А. В. Комиссаров, М. Ю. Репотецкая, Д. В. Арутюнов, 2021 